\title{
PENGARUH BUDAYA ORGANISASI TERHADAP KINERJA KARYAWAN DI PDAM TIRTA TAMAN SARI KOTA MADIUN
}

\author{
Enno Aldea Amanda ${ }^{1}$ \\ Pendidikan Akuntansi \\ Universitas PGRI Madiun \\ ennoaldeaa@yahoo.co.id
}

\author{
Satrijo Budiwibowo ${ }^{2}$ \\ Pendidikan Akuntansi \\ Universitas PGRI Madiun
}

\author{
Nik Amah ${ }^{3}$ \\ Pendidikan Akuntansi \\ Universitas PGRI Madiun
}

\begin{abstract}
ABSTRAK
Penelitian ini bertujuan untuk menguji pengaruh budaya organisasi terhadap kinerja karyawan. Populasi dalam penelitian ini adalah seluruh karyawan PDAM Tirta Taman Sari Kota Madiun dengan jumlah sampel sebanyak 102 karyawan dengan menggunakan teknik proportionate stratified random sampling. Analisis data yang digunakan dalam penelitian ini menggunakan regresi linier sederhana. Hasil penelitian menunjukan adanya pengaruh yang positif dan signifikan budaya organisasi terhadap kinerja karyawan pada PDAM Tirta Taman Sari Kota Madiun karena budaya organisasi yang baik dapat menciptakan situasi yang dapat mendorong karyawan peningkatan kinerja dan mendapatkan hasil yang maksimal. Perusahaan dapat menciptakan iklim budaya organisasi yang baik dan positif dengan merumuskan nilai dan aturan yang memiliki arah mencapai tujuan perusahaan dan memberikan pengetahuan terhadap pelanggan. Karyawan diharapkan mampu mengikuti budaya organisasi secara maksimal terutama pada kesepakatan untuk melaksanakan nilai-nilai dan aturan yang ada sehingga dapat meningkatkan kinerja.
\end{abstract}

Kata Kunci : Budaya organisasi; Kinerja karyawan; Badan Usaha Milik Daerah

\begin{abstract}
This study aims to examine the influence of organizational culture on employee performance. The population in this research is all employees of PDAM Kota Tirta Taman Sari Madiun with total sample 102 employees by using proportional stratified random sampling technique. Data analysis used in this research use simple linear regression. The results showed that there is a positive and significant influence of organizational culture on employee performance at PDAM Tirta Taman Sari Kota Madiun because good organizational culture can create situation that can encourage employees to improve their performance and get maximum result. Companies can create a positive and positive organizational culture climate by formulating values and regulations that can direct them to achiev company goals and providing knowledge to customers. Employees are expected to follow organizational culture optimally, especially on agreements to apply existing values and rules to improve performance.
\end{abstract}

Keywords: $\begin{aligned} & \text { Organizational culture; Employee performance; } \\ & \text { Regional owned enterprises }\end{aligned}$

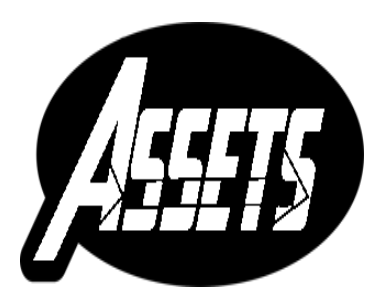

ASSETS

Jurnal Akuntansi dan Pendidikan

Vol. 6 No. 1

Hlmn. 1-12

Madiun, April 2017 p-ISSN: 2302-6251 e-ISSN: 2477-4995

Artikel masuk: 28 Februari 2017 Tanggal diterima: 19 Maret 2017 


\section{ASSEIS JURNAL AKUNTANSI DAN PENDIDIKAN

\section{PENDAHULUAN}

Keberhasilan suatu organisasi atau lembaga dalam mencapai tujuanya tidak terlepas dari sumber daya manusia yang dimiliki, karena sumber daya manusia yang akan mengatur dan mengelola sumber daya yang lain yang dimiliki organisasi untuk membantu mewujudkan tujuan organisasi. Organisasi maupun lembaga harus memiliki sumber daya manusia yang berkompeten dan memiliki tingkat kinerja yang tinggi dalam menjalankan tugas - tugas yang dibebankan oleh organisasi.

Kinerja karyawan merupakan penilaian yang dilakukan secara sistematis untuk mengetahui hasil pekerjaan karyawan dan kinerja organisasi, selain itu juga untuk menentukan pelatihan kerja secara tepat. Kinerja seorang karyawan mempunyai hal yang bersifat individual, karena setiap karyawan memiliki tingkat kemampuan yang berbeda beda dalam mengerjakan tugasnya. Selain sebagai pelaksana tugas, karyawan juga merupakan sumber daya yang penting bagi perusahaan, karena memiliki bakat, tenaga dan kreativitas yang sangat dibutuhkan oleh perusahaan untuk mencapai tujuanya. Untuk mendapatkan suatu hasil kerja yang baik dan sesuai dengan tujuan organisasi maka setiap pimpinan suatu organisasi dapat dipastikan mempunyai suatu aturan dan ketentuan yang dituangkan dalam bentuk kebijakan. Kebijakan ini dibuat dengan maksud agar setiap komponen organisasi melaksanakan tugas sesuai dengan tujuan yang telah ditetapkan dan tentunya akan meningkatkan kinerja karyawan.

Kinerja adalah suatu kualitas hasil kerja pegawai dalam menjalankan pekerjaanya selama waktu tertentu, melalui proses kerja yang sesuai standar perusahaan. Kinerja pegawai memiliki peran penting dalam menemukan keberhasilan suatu organisasi untuk mencapai tujuan yang telah ditetapkan. Berikut ini adalah pengertian menurut para ahli mengenai kinerja. Menurut Torang (2014: 74) kinerja adalah kuantitas dan kualitas hasil kerja individu atau sekelompok individu dalam organisasi untuk melaksanakan tugas pokok dan fungsi yang berpedoman pada norma, standar operasional prosedur, kriteria dan ukuran yang telah ditetapkan atau yang berlaku dalam organisasi. Kinerja karyawan dapat dikatakan tinggi dan berkualitas jika karyawan tersebut cakap, mampu, terampil, bermoral baik dan mempunyai kedisiplinan yang tinggi. Seorang karyawan bisa merasa bangga dan mempunyai kepuasan tersendiri dengan prestasi yang diperoleh dari pencapaian hasil kerja yang diberikan oleh perusahaan. Dengan demikian keberhasilan suatu perusahaan ditentukan dari bagaimana kinerja karyawan yang ada didalam perusahaan.

Untuk mengetahui bagaimana kinerja karyawan, harus ditetapkan suatu penilaian kinerja. Penilaian kinerja merupakan suatu metode mengevaluasi dan menghargai kinerja seorang karyawan. Penilaian kinerja dilakukan untuk memberi tahu karyawan apa yang diharapkan pengawas untuk membangun pemahaman yang lebih baik satu sama lain. Ada tiga elemen penting dalam proses penilaian kinerja diantaranya; standar penilaian, kriteria dan pengukuran (Darodjat, 2015: 127). Hal yang harus diperhatikan dalam menyusun standar penilaian kinerja adalah validity, agreement, realism, dan objectivity (Darodjat, 2015: 127). Selanjutnya kriteria penilaian kinerja meliputi 3 (tiga) dimensi people-based criteria, product-based criteria dan behaviorbased criteria. Elemen penilaian kinerja yang berikutnya adalah pengukuran yaitu membandingkan antara standar yang ditetapkan dengan kinerja sebenarnya yang terjadi. Adapun manfaat penilaian kinerja yaitu untuk memberikan kesempatan kepada karyawan mengambil tindakan - tindakan perbaikan sesuai dengan kriteria yang dimaksudkan oleh perusahaan. Hal itu ditujukan untuk meningkatkan kinerja melalui feedback yang diberikan oleh organisasi atau perusahaan. Dengan demikian, 
penilaian kinerja bukan hanya mengeliminasi tindakan yang kurang bermanfaat bagi organisasi melainkan sebagai alat evaluasi untuk memotivasi dan mendorong karyawan meningkatkan kinerjanya melalui indikator penilaian yang ditetapkan. Beberapa indikator untuk mengukur kinerja sebagaimana dijelaskan oleh Emron dan Yohny (2016: 195) yaitu meliputi target, kualitas, waktu penyelesaian suatu pekerjaan, dan taat asas.

Pada umumnya perusahaan menerapkan beberapa kebijakan untuk meningkatkan kinerja karyawanya misalnya melalui pendidikan, pelatihan maupun pemberian kompensasi yang layak, menciptakan lingkungan kerja yang kondusif, dan pemberian motivasi. Melalui proses - proses tersebut, karyawan diharapkan akan lebih memaksimalkan tanggung jawab atas pekerjaan mereka karena para karyawan telah terbekali oleh pendidikan dan pelatihan yang tentu berkaitan dengan implementasi kerja mereka. Sedangkan pemberian kompensasi, lingkungan kerja yang baik, serta pemberian motivasi pada dasarnya adalah hak para karyawan dan merupakan kewajiban dari pihak perusahaan untuk mendukung kontribusi para karyawan dalam rangka pencapaian tujuan organisasi.

Dalam proses pencapaian tujuan organisasi ini, tentu juga akan turut dipengaruhi oleh perilaku individu yang berkepentingan untuk mewujudkan tujuan pribadi dan kelompoknya. Perilaku dari individu dan kelompok yang beragam mendorong penetapan suatu norma yang dapat mengakomodasi berbagai kepentingan individu dan kelompok untuk bersama-sama mewujudkan tujuan organisasi. Suatu norma atau pedoman yang digunakan organisasi untuk melakukan aktivitasnya inilah yang kemudian dikenal dengan budaya organisasi.

Budaya organisasi dapat didefinisikan sebagai perangkat sistem nilai - nilai (values), keyakinan-keyakinan, asumsi-asumsi atau norma-norma yang telah lama berlaku, disepakati dan diikuti oleh para anggota suatu organisasi sebagai pedoman perilaku dan pemecahan masalah- masalah organisasi (Darodjat, 2015: 236). Priansa dan Garnida (2013: 77) berpendapat bahwa budaya organisasi merupakan sistem nilai yang dikembangkan dan berlaku dalam suatu organisasi, yang menjadikan ciri khas sebagai sebuah organisasi. Sebagai sarana untuk mempersatukan kegiatan para anggota organisasi, budaya organisasi memiliki karakteristik sebagai berikut inisiatif individual, toleransi terhadap tindakan resiko, pengarahan, integrasi, dukungan manajemen, kontrol, identitas, sistem imbalan, toleransi, dan pola komunikasi (Tika, 2006:10). Karakteristik budaya organisasi ini menjadikan organisasi berfokus kepada hasil bukan hanya pada proses, lalu sejauh mana keputusan manajemen memperhitungkan efek hasil pada individu di dalam organisasi itu. Budaya organisasi ini juga mengenai sejauh mana karyawan mencermati pekerjaan lebih presisi dan memfokuskan pada hal- hal yang rinci.

Budaya organisasi mempunyai beberapa fungsi yaitu memberi batasan untuk mendefinisikan peran sehingga memperlihatkan perbedaan yang jelas antar organisasi, memberikan pengertian identitas terhadap sesuatu yang lebih besar dibandingkan minat anggota organisasi secara perorangan, menunjukan stabilitas sistem sosial, dan pada akhirnya budaya organisasi dapat membentuk pola pikir dan perilaku anggota organisasi. Indikator budaya organisasi meliputi kesadaran diri anggota organisasi, keagresifan dalam menetapkan tujuan, kepribadian yang baik, performa, orientasi tim dimana anggota melakukan kerja sama yang baik serta melakukan komunikasi dan koordinasi yang efektif. Proses terbentuknya budaya organisasi dimulai dari munculnya gagasan- gagasan atau jalan keluar yang kemudian tertanam dalam suatu budaya dalam organisasi bisa bermula dari manapun, dari perorangan atau kelompok, dari tingkat bawah atau puncak. 


\section{ASSEIS JURNAL AKUNTANSI DAN PENDIDIKAN

Budaya organisasi cenderung membentuk standar etika yang tinggi diantara para anggotanya dalam toleransi resiko. Jika suatu budaya kuat dan mendukung standar etika yang tinggi, maka akan memiliki pengaruh yang sangat ampuh dan positif terhadap perilaku pekerja. Untuk menciptakan budaya organisasi yang beretika perusahaan yang diwakili oleh manajer harus menekankan pada pembangunan kekuatan pekerja, memberikan imbalan yang lebih dari pada memberikan hukuman, serta menekankan pada vitalitas pada pertumbuhan dari individu.

Budaya Organisasi dalam sebuah organisasi atau perusahaan biasanya dikaitkan dengan nilai, norma, sikap dan etika kerja yang dipegang bersama oleh setiap komponen organisasi. Unsur- unsur ini untuk mengawasi perilaku karyawan, cara mereka berfikir, kerja sama dan berinteraksi dengan lingkunganya. Jika budaya organisasi baik maka akan dapat meningkatkan kinerja karyawan dan akan dapat menyumbangkan keberhasilan kepada perusahaan. Seperti hasil penelitian dari Fisla dan Tuti (2007) serta Nel Arianty (2014) yakni terdapat pengaruh yang signifikan antara budaya organisasi dengan kinerja karyawan.

Berdasarkan pengamatan peneliti, penerapan budaya organisasi di PDAM Tirta Taman Sari Kota Madiun dirasakan kurang maksimal, dimana masih ada karyawan yang kurang disiplin dalam menjalankan pekerjaannya. Hal ini terlihat dari sikap dan perilaku karyawan dalam memberikan pelayanan yang belum memberikan kepuasan kepada konsumen PDAM. Sesuai hasil wawancara peneliti dengan konsumen PDAM, hal yang sering dikeluhkan adalah durasi pelayanan terhadap komplain konsumen direspon dalam waktu yang cukup lama. Hal ini menyebabkan masih ada keluhan dari konsumen PDAM yang berarti terdapat nilai-nilai atau norma-norma organisasi yang belum diterapkan oleh karyawan. Kondisi ini juga menyebabkan kepuasan kerja karyawan juga mengalami penurunan yang akibatnya akan berpengaruh pada penurunan kinerja karyawan. Dari segi pelayanan kepada konsumen secara online, peneliti mengamati bahwa keluhan konsumen melalui online service ditanggapi petugas dengan durasi waktu 1 hari. Dari fenomena yang ada serta latar belakang masalah yang telah dijabarkan sebelumnya, peneliti hendak membuktikan adanya pengaruh budaya organisasi terhadap kinerja karyawan PDAM Tirta Taman Sari Kota Madiun.

\section{METODE PENELITIAN}

Penelitian ini dilaksanakan di PDAM Tirta Taman Sari Kota Madiun yang beralamatkan di Jln. Sulawesi no. 18 Madiun. Jenis penelitian ini adalah penelitian kuantitatif. Desain penelitian yang akan digunakan dalam penelitian ini hubungan kausal. Menurut Sugiyono (2015: 62) hubungan kausal adalah hubungan yang bersifat sebab akibat. Sumber data adalah sumber data primer yaitu sumber data yang langsung memberikan data kepada pengumpul data. Data primer dalam penelitian ini berupa jawaban pertanyaan yang diajukan kepada responden yang mempengaruhi Budaya Organisasi terhadap kinerja karyawan pada PDAM Tirta Taman Sari Kota Madiun. Selain data primer, penelitian juga menggunakan data sekunder yaitu sumber yang tidak langsung memberikan data kepada pengumpul data (Sugiyono, 2015: 187). Sumber data sekunder berupa data jumlah karyawan yang ada di PDAM Tirta Taman Sari Kota Madiun.

Populasi dalam penelitian ini adalah seluruh karyawan PDAM Tirta Taman Sari Kota Madiun sejumlah 138 karyawan. Penentuan sampel pada penelitian ini menggunakan rumus Slovin, sehingga diperoleh jumlah sampel sebanyak 102 karyawan. Teknik pengambilan sampel menggunakan Probability Sampling yaitu teknik Proportionate Stratified Random Sampling. Teknik pengumpulan data dengan 
menggunakan kuesioner dan observasi. Pengisian kuesioner ini diukur menggunakan skala likert skala lima dengan item pernyataan di lampiran satu.

Teknik analisis data yang digunakan dalam penelitian ini yang pertama adalah dengan uji instrumen yaitu validitas dan reliabilitas, yang kedua analisis deskriptif meliputi deskriptif presentase, deskripsi statistik (meliputi mean, minimum, maksimum, dan standar deviasi). Selanjutnya analisis yang ketiga adalah dengan pengujian asumsi klasik, uji asumsi klasik ini meliputi uji normalitas dan uji homogenitas. Validitas angket diuji teknik validitas logis, yakni validitas instrumen yang diukur dari kecocokan sehingga secara logika dapat diterima. Data yang diperoleh kemudian dihitung menggunakan Product Moment (Arikunto, 2013:213). Kriteria penyaji jika $r$ hitung $>r$ table maka item dinyatakan valid. Untuk uji validitas dalam penelitian ini, peneliti menggunakan rumus korelasi product moment. Instrumen dinyatakan valid jika butir soal mempunyai korelasi rxy > 0,193.

Reliabilitas merupakan alat untuk mengukur suatu kuesioner yang merupakan indicator dari variable dan konstruk dilakukan uji reliabilitas dengan menggunakan rumus alpha (Ghozali, 2011: 47). Kriteria pengujian jika $\mathrm{r}$ hitung $>\mathrm{t}$ table maka item dinyatakan valid dan reliabel. Terkait hasil perhitungan menyatakan semua valid maka data atau instrument penelitian tersebut dapat digunakan untuk melakukan penelitian.

Uji normalitas digunakan pada model regresi digunakan untuk mengetahui apakah populasi data berdistribusi normal atau tidak (Priyatno, 2010 : 71). Uji normalitas dalam penelitian ini dilakukan dengan bantuan program SPSS release 22.0 for windows melalui uji One sample kolmogorov-smirnov, metode pengambilan keputusannya yaitu: (1) jika signifikansi (Asymp.sig) $>0,05$, maka residual berditribusi normal, (2) jika signifikansi (Asymp.sig) <0,05, maka residual tidak berdistribusi normal.

Uji homogenitas digunakan untuk mengetahui apakah beberapa varian populasi data adalah sama atau tidak. (Priyatno, 2010:76) Pengujian homogenitas dalam penelitian ini menggunakan uji one way ANOVA dalam seri program statistik (SPSS, release 22.0 for windows), dengan kriteria pengujanya yaitu: (1) jika signifikansi $<0,05$, maka varian kelompok data tidak sama, (2) jika signifikansi > 0,05, maka varian kelompok data adalah sama.

Persamaan regresi linier sederhana dapat dirumuskan (Priyatno,2010:55) sebagai berikut:

$$
\mathrm{Y}=\mathrm{a}+\mathrm{b} \mathrm{X}
$$

Uji statistik digunakan untuk menguji pengaruh variabel independen $(X)$ secara parsial terhadap variabel dependen $(\mathrm{Y})$, apakah pengaruhnya signifikan atau tidak. Rumus uji statistik t menurut Priyatno (2010:59) adalah:

$$
t_{\text {hitung }}=\frac{b}{S b}
$$

\section{HASIL PENELITIAN DAN PEMBAHASAN}

Uji validitas dilakukan dengan menghitung rumus statistik, dalam penelitian ini pengujian dilakukan terhadap 102 responden. Dengan mengambil keputusan berdasarkan valid apabila $r_{\text {hitung }}>r_{\text {tabel. }}$. Hasil uji validitas menunjukan bahwa seluruh pernyataan untuk variabel budaya organisasi dan kinerja karyawan memiliki ststus valid.

Uji reliabilitas dilakukan dengan menghitung rumus statistic, dalam penelitian ini pengujian dilakukan terhadap 102 responden. Dengan dasar pengambilan 


\section{ASSETS}

keputusan jika nilai Cronbach Alpha lebih dari 0,193 dinyatakan reliabel. Adapun hasil pengolahan data terdapat pada tabel dibawah ini:

Tabel 1. Hasil Uji Reliabilitas

\begin{tabular}{clll}
\hline No & \multicolumn{1}{c}{ Variabel } & Cronbach Alpha & Hasil \\
\hline 1 & Budaya organisasi $(\mathrm{X})$ & 0,712 & Reliabel \\
2 & Kinerja karyawan $(\mathrm{Y})$ & 0,905 & Reliabel \\
\hline
\end{tabular}

Berdasarkan tabel diatas terlihat bahwa seluruh variabel penelitian memiliki nilai Cronbach Alpha yang lebih besar dari 0,193 sehingga dapat disimpulkan bahwa semua variabel yang digunakan dalam penelitian ini berstatus reliabel.

Berdasarkan hasil analisis dengan menggunakan program SPSS release 17.0 for windows melalui uji One sample kolmogorov-smirnov, dengan hasil output SPSS yaitu:

Tabel 2. Uji Normalitas Data dengan One-Sample Kolmogorov-Smirnov

\begin{tabular}{llcc}
\hline & & Budaya & Kinerja \\
\hline $\mathrm{N}$ & & 102 & 102 \\
Normal Parameters ${ }^{\mathrm{a}, \mathrm{b}}$ & Mean & 31,0882 & 32,2549 \\
& Std. Deviation & 4,06410 & 4,07525 \\
Most & Extreme Absolute & 0,089 & 0,082 \\
Differences & Positive & 0,080 & 0,082 \\
& Negative & $-0,089$ & $-0,078$ \\
Kolmogorov-Smirnov Z & 0,896 & 0,825 \\
Asymp. Sig. (2-tailed) & & 0,398 & 0,504 \\
\hline
\end{tabular}

Berdasarkan tabel di atas, dapat ditarik kesimpulan dengan melihat nilai Asymp Sig (2-tailed) dari masing-masing data setiap variabel sebagai berikut (1) variabel Budaya Organisasi $\quad=0,398>0,05$, artinya residual berdistribusi normal. (2) Variabel Kinerja Karyawan $\quad=0,504>0,05$, artinya residual berdistribusi normal. Hasil kesimpulan di atas menunjukkan bahwa data variabel budaya organisasi, dan kinerja karyawan berdistribusi normal.

Uji homogenitas digunakan untuk mengetahui apakah data memiliki varian yang sama atau berbeda. Pengujian homogenitas dalam penelitian ini menggunakan uji one way ANOVA dalam seri program statistik (SPSS, release 17.0 for windows), dengan hasil perhitungannya:

Tabel 3. Hasil Uji Homogenitas

\begin{tabular}{llcccc}
\hline & & Levene & & & \\
& & Statistic & df1 & df2 & Sig. \\
\hline X1.Y & Based on Mean & 0,007 & 1 & 202 & 0,962 \\
& Based on Median & 0,000 & 1 & 202 & 0,976 \\
Based on Median and with adjusted df & 0,000 & 1 & 201,995 & 0,976 \\
Based on trimmed mean & 0,005 & 1 & 202 & 0,969 \\
\hline
\end{tabular}

Berdasarkan tabel 4.15 di atas, menunjukkan nilai Sig pada kolom Based on Mean $=0,962>0,05$, Artinya varian kelompok data homogen. 
Sehingga diperoleh persamaan regresi sederhana $Y=13,20+0,613$.X. berdasarkan persamaan regresi linier sederhana tersebut diketahui nilai konstanta sebesar 13,20. Artinya jika nilai budaya organisasi $(X)$ adalah 0 , maka kinerja karyawan (Y) nilainya positif yakni 13,20. Sedangkan koefisien regresi variabel budaya organisasi (X) sebesar 0,613. Artinya jika nilai budaya organisasi mengalami kenaikan 1 angka maka nilai kinerja karyawan (Y) akan naik sebesar 0,613. Koefisien bernilai positif artinya antara budaya organisasi dengan kinerja karyawan terjadi pengaruh yang positif. Artinya semakin naik nilai budaya organisasi maka semakin meningkat nilai kinerja karyawan.

$$
\begin{array}{ll}
Y & =a+b \cdot X \\
Y & =13,20+0,613 \cdot X
\end{array}
$$

Sehingga diperoleh $t_{\text {hitung }}=7,750$, adapun $t_{\text {tabel }}$ pada $N=102-2$ diperoleh hasil 1,984 pada taraf signifikansi 95\%. Dengan demikian $t_{\text {hitung }}>t_{\text {tabel }}$ atau 7,750 $>1,984$ artinya Ha diterima dan Ho ditolak. Artinya ada pengaruh budaya organisasi terhadap kinerja karyawan pada PDAM Tirta Taman Sari Kota Madiun.

$$
t_{\text {hitung }}=\frac{b}{S b}=\frac{0,613}{0,0791}=7,750
$$

Berdasarkan hasil analisis data penelitian di atas menunjukkan bahwa peneliti mengemukakan pendapat bahwa budaya organisasi memiliki pengaruh yang signifikan dalam memberikan sumbangan faktor yang mempengaruhi hasil kinerja karyawan. Hal tersebut menjelaskan bahwa jika tingkat budaya organisasi meningkat, maka kinerja karyawan pada PDAM Tirta Taman Sari Kota Madiun juga akan ikut meningkat.

Menurut Torang (2014: 174) Kinerja (performance) adalah kuantitas dan atau kualitas hasil kerja individu atau sekelompok di dalam organisasi dalam melaksanakan tugas pokok dan fungsi yang berpedoman pada norma, standar operasional prosedur, kriteria dan ukuran yang telah ditetapkan atau yang berlaku dalam organisasi. Hal ini menunjukkan bahwa kinerja suatu karyawan dapat dilihat dari kemampuannya dalam Berorganisasi. Seperti pengertian kinerja tersebut, maka jika budaya berorganisasi suatu karyawan baik dan positif, maka akan meningkatkan kinerjanya. Kinerja karyawan memberikan manfaat yang besar pada suatu organisasi, karena dengan kinerja karyawan dapat meningkatkan produktivitas kerja, menghemat sumber daya yang dimiliki oleh manajemen maupun organisasi secara keseluruhan, mempertahankan stabilitas kinerja karyawan serta membantu organisasi untuk bertahan dan beradaptasi terhadap perubahan lingkungan. Ada tiga faktor utama yang dapat mempengaruhi bagaimana tingkatan kinerja individu antara lain budaya organisasi.

Dalam penelitian menunjukkan bahwa hasil kinerja karyawan yakni 42 karyawan mendapatkan nilai sangat tinggi, 45 karyawan mendapatkan nilai tinggi, dan 15 karyawan mendapatkan nilai sedang dalam kinerjanya. Hal ini menandakan bahwa kinerja karyawan yang dilakukan didominasi kriteria sangat tinggi dan tinggi atau positif. Meskipun begitu manajemen atau perusahaan hendaknya selalu berusaha menjaga produktifitas kinerja karyawan melalui pemenuhan berbagai faktor yang mempengaruhi kinerja karyawan, seperti yang telah disebutkan di kajian teori. Karena berdasarkan data yang diperoleh dari kuisioner hasil penilaian kinerja karyawan di PDAM Tirta Taman Sari Kota Madiun diketahui bahwa variabel kinerja karyawan 


\section{ASSEES JURNAL AKUNTANSI DAN PENDIDIKAN

mendapatkan skor terendah 2,4 pada butir item no 4 pada indikator kualitas. Dengan pernyataan karyawan merasa tidak puas dengan hasil pekerjaan yang dilakukan.

Kondisi ini tentu saja dipengaruhi oleh beberapa faktor, antara lain budaya organisasi. Budaya organisasi ini merupakan salah satu bentuk aturan dalam bekerja dalam suatu organisasi atau kelompok untuk mengarahkan, mempengaruhi dan menggerakkan orang lain dalam kelompok tersebut agar dapat melaksanakan tugasnya sesuai dengan perencanaan yang telah ditetapkan, sehingga mendorong gairah kerja anggotanya agar mereka mau bekerja keras dengan memberikan semua kemampuan dan keterampilannya untuk mewujudkan tujuan suatu organisasi.

Darodjat (2015: 236) menjelaskan bahwa budaya organisasi dapat didefinisikan sebagai perangkat sistem nilai - nilai (values), keyakinan-keyakinan, asumsi-asumsi atau norma-norma yang telah lama berlaku, disepakati dan diikuti oleh para anggota suatu organisasi sebagai pedoman perilaku dan pemecahan masalah- masalah organisasi. Sebagaimana teori tersebut dapat dijelaskan bahwa apabila dalam sebuah organisasi atau perusahaan terdapat budaya organisasi yang positif, maka anggota atau karyawan yang berada di dalamnya akan memiliki sikap yang taat dan patuh terhadap nilai - nilai dan norma yang disepakati dalam budaya organisasi tersebut. Hal ini juga dijelaskan oleh Emron dan Yohny (2016: 129) mengemukakan tentang fungsi budaya dalam organisasi menjadi empat fungsi yairu : 1) memberikan nuansa yang membedakan dengan organisasi lain dan kesan tersendiri sehingga memberikan citra positif bagi organisasi/ perusahaan dimata publik atau pelanggan; 2) memiliki simbol dan nilai - nilai yang menjadi kebanggaan anggota yang ada didalamnya; 3 ) membimbing perilaku - perilaku anggotanya kearah pemikiran konstruktif, berkontribusi positif, dan bekerja efektif dalam mencapai tujuan organisasi/ perusahaan; 4) membangun kerja sama tim yang solid dan rasa kebersamaan yang tinggi sesama anggota. Dengan demikian sama halnya dengan kinerja karyawan jika budaya organisasi yang ada meningkat, maka kinerja karyawan juga akan meningkat, dikarenakan dengan adanya budaya organisasi terjadi interaksi yang positif dan kerjasama tim yang baik sehingga pekerjaan berjalan efektif.

Dalam penelitian menunjukkan bahwa hasil budaya organisasi karyawan sangat tinggi yaitu 32 karyawan berpendapat sangat tinggi, 49 karyawan berpendapat tinggi, dan 21 karyawan berpendapat sedang terhadap budaya organisasi. Hal ini menandakan bahwa budaya organisasi karyawan di PDAM Tirta Taman Sari Kota Madiun memang tinggi. Meskipun begitu manajemen atau perusahaan hendaknya selalu berusaha menjaga atau bahkan meningkatkan budaya organisasi melalui berbagai faktor yang mempengaruhi budaya organisasi seperti yang disebutkan pada kajian teori. Karena berdasarkan hasil penelitian budaya organisasi di PDAM Tirta taman Sari Kota Madiun diketahui bahwa variabel budaya organisasi mendapatkan skor terendah 3,0 pada butir item no 6 pada indikator kepribadian. Dengan pernyataan karyawan kurang memperdulikan pekerjaan yang telah dilakukan oleh sesama bagian. Dari hasil perhitungan persamaan regresi sederhana menunjukkan $Y=13,20+0,613$.X. Artinya jika nilai budaya organisasi $(X)$ adalah 0 , maka kinerja karyawan $(Y)$ nilainya positif yakni 13,20. Sedangkan koefisien regresi variabel budaya organisasi $(X)$ sebesar 0,613 . Artinya jika nilai budaya organisasi mengalami kenaikan 1 angka maka nilai kinerja karyawan (Y) akan naik sebesar 0,613. Koefisien bernilai positif artinya antara budaya organisasi dengan kinerja karyawan terjadi hubungan yang positif. Artinya semakin naik nilai budaya organisasi maka semakin meningkat nilai kinerja karyawan. Sedangkan hasil koefisien regresi dengan uji statistik $t$ menunjukkan bahwa dalam penelitian ini diperoleh koefisien regresi sebesar 7,750 lebih besar dari taraf signifikansi 
$95 \%$ sebesar 1,984 atau $7,750>1,984$. Artinya ada pengaruh budaya organisasi terhadap kinerja karyawan pada PDAM Tirta Taman Sari Kota Madiun.

Indikator variabel budaya organisasi yang paling menonjol adalah kesadaran diri dan performa, dengan nilai rata-rata jawaban responden pada indikator tersebut ialah sebesar 3,15. Artinya setuju jika mendapat kepuasan atas pekerjaan yang dilakukan, serta setuju jika karyawan tidak menunda pekerjaan yang telah diberikan pimpinan. Dengan kesadaran diri berupa pemerolehan kepuasan atas pekerjaan yang dilakukan, akan memberikan iklim atau situasi budaya organisasi yang baik dan positif yang mampu meningkatkan kinerja karyawan. Selanjutnya dengan performa dalam hal bekerja secara loyal artinya tidak menunda pekerjaan yang telah diberikan pimpinan, juga akan mampu meningkatkan kinerja karyawan.

Menanggapi hasil tersebut, peneliti mengemukakan pendapat bahwa budaya organisasi memiliki hubungan yang signifikan dalam memberikan sumbangan faktor yang mempengaruhi hasil kinerja karyawan. Secara rasional kinerja karyawan dipengaruhi oleh seberapa baik karyawan dalam bekerja, sedangkan karyawan dapat bekerja dengan baik apabila ada dorongan baik dari dalam diri sendiri maupun dorongan dari luar seperti budaya organisasi yang baik dan positif. Salah satu upaya untuk mendorong agar karyawan dapat bekerja dengan baik dan efektif adalah mengatur nilai-nilai dan aturan dalam budaya organisasi yang lebih baik, dan positif. Hal ini menunjukkan banyak sekali faktor yang dapat mempengaruhi sumber daya manusia dalam menjalankan kinerja karyawan, antara lain faktor yang berasal dari dalam diri sumber daya manusia sendiri maupun dari luar dirinya. Setiap pekerja mempunyai kemampuan berdasar pada pengetahuan dan keterampilan, kompetensi yang sesuai dengan pekerjaannya, dan budaya organisasi. Namun, pekerja juga mempunyai kepribadian, sikap dan perilaku yang dapat mempengaruhi kinerja karyawan. Dengan demikian, melalui budaya organisasi dapat mendorong agar karyawan memiliki semangat yang tinggi dalam bekerja sehingga mampu meningkatkan kinerja karyawan.

\section{SIMPULAN}

Kesimpulan dari penelitian ini adalah secara keseluruhan rata-rata tingkat budaya organisasi adalah tinggi atau cenderung dalam hal yang positif. Kedua, kondisi kinerja karyawan PDAM Tirta Taman Sari Kota Madiun secara keseluruhan memiliki nilai rata-rata tinggi. Ketiga, ada pengaruh yang positif dan signifikan budaya organisasi terhadap kinerja karyawan pada PDAM Tirta Taman Sari Kota Madiun. Terdapat nilai-nilai dan aturan yang disepakati dan dilaksanakan dalam budaya organisasi. Jika budaya organisasi yang tercipta baik dan positif, maka akan memberikan dampak pada peningkatan kinerja karyawan.

Saran peneliti untuk kemajuan perusahaan, pemimpin hendaknya tidak segan untuk memberikan contoh kinerja yang bagus, selain itu juga dapat meningkatkan kepedulian antara pimpinan dan karyawan, sehingga dapat menciptakan kondisi budaya organisasi yang positif dan dapat meningkatkan kinerja karyawan. Sedangkan, saran untuk kemajuan perusahaan hendaknya karyawan berperan aktif dalam meberikan saran, ide atau gagasan- gagasan yang membangun, dengan begitu akan meningkatkan produktivitas kerja karyawan dan perusahaan. Selain itu juga menciptakan suasana kerja yang menyenangkan dengan didukung oleh atasan yang penuh perhatian terhadap bawahanya. Karyawan hendaknya dapat meningkatkan kedisiplinan dalam bekerja guna meningkatkan produktivitas kerja dalam perusahaan. 


\section{DAFTAR PUSTAKA}

Darodjat, Achmad Tubagus. (2015) . Konsep - Konsep Dasar Manajemen Personalia. Bandung: Anggota Ikapi.

Emron Edison dan Yohny Imas. (2016). Manajemen Sumber Daya Manusia. Bandung : Alfabeta.

Fisla \& Tuti. (2007). Pengaruh Budaya Organisasi terhadap Kinerja Karyawan Politeknik Negeri Padang, Jurnal Ekonomi dan Bisnis Volume 2 (1).

Nel Arianty. (2014). Pengaruh Budaya Organisasi terhadap Kinerja Pegawai. Jurnal Manajemen dan Bisnis, Volume 14 no 02, Oktober 2014.

Priansa, D Juni dan Garnida Agus. 2013. Manajemen Perkantoran Efektif, Efisien dan Professional. Bandung: Alfabeta.

Priyatno, Duwi. (2010). Paham Analisa Data dengan SPSS. Yogyakarta: Mediakom.

Sugiyono. (2015). Metode Penelitian Kuantitatif, Kualitatif dan Kombinasi (Mixed Methods). Bandung : Alfabeta.

Tika, Pabundu. (2006). Budaya Organisasi dan Peningkatan Kinerja Perusahaan. Jakarta: Bumi Aksara.

Torang, Syamsir. (2014). Organisasi Manajemen : Perilaku, Struktur, Budaya \& Perubahan Organisasi. Bandung: Alfabeta. 


\section{LAMPIRAN 1}

\section{KUISIONER PENELITIAN \\ "PENGARUH BUDAYA ORGANISASI TERHADAP KINERJA KARYAWAN PDAM TIRTA TAMAN SARI KOTA MADIUN"}

Dengan Hormat,

Saya Enno Aldea Amanda, mahasiswa Fakultas Keguruan dan Ilmu Pendidikan (FKIP), Program Studi Pendidikan Akuntansi Universitas PGRI MADIUN. Saya sedang menyusun sebuah skripsi sebagai salah satu syarat untuk memperoleh gelar Sarjana Strata 1 (S1) dengan judul "Pengaruh Budaya Organisasi Terhadap Kinerja Karyawan PDAM Tirta Taman Sari Kota Madiun". Saya sangat membutuhkan pendapat dari responden untuk melengkapi penelitian ini.

Besar harapan saya, kiranya Bapak/Ibu bersedia mengisi kuisioner ini dengan sejujur- jujurnya. Atas bantuan Bapak/Ibu saya ucapkan terima kasih dan selamat mengisi kuisioner ini.

Hormat saya,

Enno Aldea Amanda

\section{A. Petunjuk Pengisian}

1. Mohon bantuan dan kesediaan untuk menjawab seluruh pertanyaan yang telah tersedia

2. Beri tanda $(\sqrt{ })$ pada pertanyaan yang sesuai dengan kondisi sesungguhnya pada kolom yang telah disediakan

3. Terdapat empat (4) pilih jawaban yang tersedia untuk masing - masing pertanyaan:

SS = Sangat Setuju

$S$ = Setuju

TS $=$ Tidak Setuju

STS $=$ Sangat Tidak Setuju

B. Identitas Responden

1. Nama

2. Jenis Kelamin : Laki - Laki / Perempuan*

3. Usia

4. Pendidikan Terakir : SD/ SMP /SLTA /D3 /S1 /S2*

5. Pangkat/Golongan :

$\begin{array}{lllll}\mathrm{C} 1 \square & \mathrm{C} 2 \square & \mathrm{C} 3 \square & \mathrm{C} 4 \square & \mathrm{C} 5 \square \\ \mathrm{B} 2 \square & \mathrm{B} 3 \square & \mathrm{B} 4 \square & \mathrm{D} 1 \square & \mathrm{D} 2 \square\end{array}$

6. Masa Kerja

$\square<5$ tahun $\square 5-10$ tahun $\square>10$ tahun

C. Budaya Organisasi

\begin{tabular}{|c|l|c|c|c|c|}
\hline NO & \multicolumn{1}{|c|}{ PERNYATAAN } & SS & S & TS & STS \\
\hline 1 & $\begin{array}{l}\text { Karyawan sebaiknya mendapat kepuasan atas } \\
\text { pekerjaan yang dilakukan }\end{array}$ & & & & \\
\hline 2 & Karyawan merasa sangat kurang dalam & & & & \\
\hline
\end{tabular}




\section{ASSETS}

\begin{tabular}{|c|l|c|c|c|c|}
\hline NO & \multicolumn{1}{|c|}{ PERNYATAAN } & SS & S & TS & STS \\
\hline 3 & mengembangkan diri dan kemampuanya & & & & \\
\hline 4 & $\begin{array}{l}\text { Karyawan sebaiknya menetapkan rencana kerja dan } \\
\text { berusaha menyelesaikanya dengan baik }\end{array}$ & $\begin{array}{l}\text { Dalam melaksanakan setiap pekerjaan, karyawan tidak } \\
\text { memiliki inisiatif, selalu bergantung pada petunjuk } \\
\text { pimpinan }\end{array}$ & & & \\
\hline 5 & $\begin{array}{l}\text { Karyawan saling menghargai, menghormati dan } \\
\text { melayani pelanggan dengan baik }\end{array}$ & & & \\
\hline 6 & $\begin{array}{l}\text { Karyawan kurang memperdulikan pekerjaan yang } \\
\text { telah dilakukan oleh sesama bagian }\end{array}$ & $\begin{array}{l}\text { Karyawan selalu mengutamakan performa kualitas } \\
\text { dalam menyelesaikan pekerjaanya }\end{array}$ & & & \\
\hline 7 & $\begin{array}{l}\text { Karyawan tidak menunda pekerjaan yang telah } \\
\text { diberikan pimpinan }\end{array}$ & $\begin{array}{l}\text { Karyawan bekerja sama dengan rekan kerja dalam tim } \\
\text { maupun koordinasi }\end{array}$ & & & \\
\hline 10 & $\begin{array}{l}\text { Karyawan menolak ide ide yang diberikan tim kerja } \\
\text { untuk kemajuan perusahaan }\end{array}$ & & & \\
\hline
\end{tabular}

\section{Kinerja Karyawan}

\begin{tabular}{|c|c|c|c|c|c|}
\hline NO & PERTANYAAN & SS & $\mathrm{S}$ & TS & STS \\
\hline 1 & $\begin{array}{l}\text { Karyawan melaksanakan pekerjaan dalam hal } \\
\text { pelayanan sesuai dengan target perusahaan }\end{array}$ & & & & \\
\hline 2 & $\begin{array}{l}\text { Target kerja yang ditetapkan karyawan tidak sesuai } \\
\text { dengan standart kerja perusahaan }\end{array}$ & & & & \\
\hline 3 & $\begin{array}{l}\text { Untuk memenuhi kualitas yang baik, karyawan } \\
\text { sebaiknya bekerja berdasarkan prosedur- prosedur } \\
\text { yang ada di dalam perusahaan }\end{array}$ & & & & \\
\hline 4 & $\begin{array}{l}\text { Karyawan merasa tidak puas dengan hasil pekerjaan } \\
\text { yang dilakukan }\end{array}$ & & & & \\
\hline 5 & $\begin{array}{l}\text { Karyawan merasa tidak enak (misal sungkan, malu) } \\
\text { jika pekerjaanya belum selesai }\end{array}$ & & & & \\
\hline 6 & $\begin{array}{l}\text { Karyawan sebaiknya selalu tepat waktu dalam } \\
\text { menyelesaikan pekerjaan }\end{array}$ & & & & \\
\hline 7 & $\begin{array}{l}\text { Karyawan sering tidak mentaati peraturan - peraturan } \\
\text { yang telah ditetapkan perusahaan }\end{array}$ & & & & \\
\hline 8 & $\begin{array}{l}\text { Karyawan selalu on time dan datang dikantor kurang } \\
\text { lebih } 10 \text { menit sebelum apel dimulai }\end{array}$ & & & & \\
\hline 9 & $\begin{array}{l}\text { Karyawan sebaiknya mencari tambahan pengetahuan } \\
\text { tentang hal - hal yang berkaitan dengan tugas dan } \\
\text { tanggung jawab pekerjaanya }\end{array}$ & & & & \\
\hline 10 & $\begin{array}{l}\text { Jika petunjuk kerja tidak jelas maka karyawan tidak } \\
\text { dapat mempertanggung jawabkan pekerjaanya sesuai } \\
\text { prosedur }\end{array}$ & & & & \\
\hline
\end{tabular}

